\title{
Large-scale production of recombinant miraculin protein in transgenic carrot callus suspension cultures using air-lift bioreactors
}

Yun-Ji Park' , Jong-Eun Han ${ }^{1}$, Hyoshin Lee ${ }^{2}$, Yu-Jin Jung ${ }^{3}$, Hosakatte Niranjana Murthy ${ }^{1,4}$ and So-Young Park ${ }^{1 *}$

\begin{abstract}
Miraculin, derived from the miracle fruit (Synsepalum dulcificum), is a taste-regulating protein that interacts with human sweet-taste receptors and transforms sourness into sweet taste. Since miracle fruit is cultivated in West Africa, mass production of miraculin is limited by regional and seasonal constraints. Here, we investigated mass production of recombinant miraculin in carrot (Daucus carota L.) callus cultures using an air-lift bioreactor. To increase miraculin expression, the oxidative stress-inducible SWPA2 promoter was used to drive the expression of miraculin gene under various stress treatments. An $8 \mathrm{~h}$ treatment of hydrogen peroxide $\left(\mathrm{H}_{2} \mathrm{O}_{2}\right)$ and salt $(\mathrm{NaCl})$ increased the expression of miraculin gene by fivefold compared with the untreated control. On the other hand, abscisic acid, salicylic acid, and methyl jasmonate treatments showed no significant impact on miraculin gene expression compared with the control. This shows that since $\mathrm{H}_{2} \mathrm{O}_{2}$ and $\mathrm{NaCl}$ treatments induce oxidative stress, they activate the SWPA2 promoter and consequently up-regulate miraculin gene expression. Thus, the results of this study provide a foundation for industrial-scale production of recombinant miraculin protein using transgenic carrot cells as a heterologous host.
\end{abstract}

Keywords: Agrobacterium-mediated transformation, Alternative sweetener, Carrot callus cultures, Miraculin, Plant cell culture, Recombinant protein

\section{Key points}

- Miraculin protein (a taste modifier) gene tagged with SWAP2 promoter was cloned to carrot cells.

- Transformed carrot cells were cultured in air-lift bioreactors for the production of recombinant miraculin protein.

- Effect of hydrogen peroxide, salt $(\mathrm{NaCl})$, abscisic acid, salicylic acid and methyl jasmonate were tested on miraculin gene expression.

- Treatment of hydrogen peroxide, $\mathrm{NaCl}$, increased the expression of miraculin gene by fivefold compared to control.

\footnotetext{
*Correspondence: soypark7@cbnu.ac.kr

${ }^{1}$ Department of Horticulture, Division of Animal, Horticultural and Food

Sciences, Chungbuk National University, Cheongju 28644, Republic

of Korea

Full list of author information is available at the end of the article
}

\section{Introduction}

Miraculin is a sweet protein produced from the fruit of Synsepalum dulcificum. Miraculin protein has attracted much attention as a natural alternative sweetener because it has a taste-modifying activity that transforms sour taste into sweet taste and is low in calories (Jin et al. 2013; Ezura and Hiwasa-Tanase 2018). S. dulcifica is native to West Africa and is difficult to grow on a large scale because of climatic limitations, thus making the mass production of miraculin difficult. Therefore, largescale production of miraculin for industrial purposes requires an investigation of alternative production systems using heterologous hosts (Sun et al. 2007; Yano et al. 2010).

Recently, plant systems have been studied as a platform for the production of recombinant proteins. Plants have low risk for mammalian pathogens and cost-effective production process as heterologous production systems (Huang and McDonald 2012). Methods for producing 
recombinant proteins in plants include Agrobacteriummediated transformation and transient expression via agroinfiltration, biolistics, and electroporation. In the recent past, Agrobacterium-mediated transformation is the most common method of plant transformation (Huang et al. 2018). In the present study, we have used SWPA2 promoter (obtained from sweet potato) which could over express the tagged gene under stress conditions and it has used successfully to transform the useful genes into several plants (Kim et al. 2003, 2004).

Plant cell culture has recently been considered as an alternative system for the production of recombinant proteins (Hellwig et al. 2004) and has the following advantages: (1) high growth rate, (2) ease of transformation, and (3) high protein production capacity (Corbin et al. 2016). Plant cell culture in bioreactors enables efficient, large-scale, and uniform production of recombinant proteins under controlled conditions (Huang and McDonald 2009). Three different types of bioreactors have been used for recombinant protein production in plant cell suspension cultures including stirred-tank bioreactors, air-lift bioreactors, and membrane bioreactors (Huang and McDonald 2009), and the yield of recombinant protein varies among these bioreactors. Air-lift bioreactor is suitable for growing plant cell cultures that are sensitive to physical stress because it minimizes the physical stress that occurs when cells move through the incubator (Eibl and Eibl 2008). It also has a lower operating cost than other types of bioreactors and has the advantage of easy scale-up for large-scale plant cell culture (Huang and McDonald 2012). Because of these advantages, López et al. (2014) and Corbin et al. (2016) used bioreactor cultures for recombinant protein production. However, there have been no reports on the use of bioreactors for the production of sweet proteins, such as miraculin. Therefore, research is needed to optimize bioreactor culture conditions for the mass production of miraculin in transgenic cell cultures.

In this study, we investigated recombinant miraculin production in carrot (Daucus carota L.) callus transformed by Agrobacterium tumefaciens and cultured in air-lift bioreactors. This study aims to increase the expression of the miraculin gene, driven by the SWPA2 promoter, in transgenic carrot callus through abiotic stress and light quality treatments, and to optimize the bioreactor culture system for mass production of miraculin.

\section{Materials and methods Plant material}

Carrot callus was infected with $A$. tumefaciens carrying the FLAG-tagged miraculin gene (accession no. D38598) driven with stress-inducible SWPA2 promoter (Kim et al.
2003). Transgenic callus (TC) lines were selected on callus induction medium [CI medium: Murashige and Skoog (MS) solid medium with $0.25 \mathrm{~g} \mathrm{~L}^{-1}$ casein hydrolysate; $0.22 \mathrm{mg} \mathrm{L}^{-1} \mathrm{BA} ; 1 \mathrm{mg} \mathrm{L}^{-1} 2,4-\mathrm{D} ; 30 \mathrm{~g} \mathrm{~L}^{-1}$ sucrose; and $2.4 \mathrm{~g} \mathrm{~L}^{-1}$ gelrite] containing $100 \mu \mathrm{g} \mathrm{mL}^{-1}$ kanamycin. TC lines (TC1-TC18) were cultured in CI medium at $24 \pm 1{ }^{\circ} \mathrm{C}$ in the dark for 2 weeks for further study. After 2 weeks, TC lines (TC3, TC13, TC17, TC18) with high miraculin expression and cell growth were selected and cultured in liquid CI medium for cell suspension culture at a culture density of $40 \mathrm{~g} \mathrm{~L}^{-1}$ at $100 \mathrm{rpm}$.

\section{Abiotic stress treatments}

To analyze the effect of abiotic stress on miraculin gene expression, TC3 line was treated with five stress factors including hydrogen peroxide $\left(\mathrm{H}_{2} \mathrm{O}_{2}\right)$ at 220, 440, and $880 \mu \mathrm{M}$, salt $(\mathrm{NaCl})$ at 50,100 , and $200 \mathrm{mM}$, and abscisic acid (ABA), salicylic acid (SA), and methyl jasmonate (MeJA) at 50, 100, $200 \mu \mathrm{M}$. To conduct these treatments, TC3 was pre-cultured in liquid CI medium at a culture density of $40 \mathrm{~g} \mathrm{~L}^{-1}$ for 3 days. Abiotic stress treatments were carried out at $24 \pm 1{ }^{\circ} \mathrm{C}$ at $100 \mathrm{rpm}$ for $8 \mathrm{~h}$ in the dark, with three replicates per treatment. Sampling was performed at $0 \mathrm{~h}$ (untreated control) and $8 \mathrm{~h}$ after treatment, and samples were used for miraculin expression analysis.

\section{Light quality treatment}

To determine the effect of light quality on miraculin gene expression, TC3 line was cultured under six different light qualities: dark (D), white LED (PLLCC 5450 6-pin; Its-well Co., Incheon, Korea) (W), red light $(\mathrm{R})$, blue light $(\mathrm{B})$, red1: blue1 (RB), red1: green1: blue1 (RGB). In each treatment, light intensity was maintained at $65-75 \mu \mathrm{mol} \mathrm{m}{ }^{-2} \mathrm{~s}^{-1}$, with a $16 \mathrm{~h}$ light $/ 8 \mathrm{~h}$ dark photoperiod. TC3 was cultured in CI medium at $24 \pm 1{ }^{\circ} \mathrm{C}$ under various light qualities for 3 weeks. Each light quality treatment was performed in triplicate. Miraculin gene expression was analyzed 1 week after treatment, and the fresh weight, chlorophyll content, and carotenoid content of TC were analyzed after 3 weeks of culture.

\section{Analysis of chlorophyll and carotenoid contents}

Chlorophyll and carotenoid contents of TC3 used to light quality treatment were analyzed as described previously (Boamponsem and Leung 2017). Briefly, $100 \mathrm{mg}$ TC previously frozen in liquid nitrogen was pulverized with Tissue-Lyser II (QIAGEN, Germany) in $1 \mathrm{~mL}$ of $80 \%$ acetone. After centrifugation at 13,000 rpm for $20 \mathrm{~min}$, the supernatant was transferred to a new tube, and absorbance was measured at 470, 645, and $663 \mathrm{~nm}$ using Optizen POP (Mecasys Co., Korea). 


\section{Bioreactor culture of transgenic callus}

To test the possibility of mass production of miraculin, TC3 was cultured in a 1-L air-lift bioreactor containing $\mathrm{CI}$ medium at a culture density of $40 \mathrm{~g} \mathrm{~L}^{-1}$. Culture was carried out at $24 \pm 1{ }^{\circ} \mathrm{C}$ in the dark, and aeration volume was adjusted to $0.1 \mathrm{vvm}$. Sampling was carried out every 6 days, and the experiment was terminated after 18 days. Samples were cryopreserved at $-70{ }^{\circ} \mathrm{C}$, and used for miraculin gene expression and protein production analyses.

\section{Miraculin gene expression analysis}

Reverse transcription quantitative real-time PCR (RTqPCR) was performed to analyze miraculin expression according to abiotic stress treatment and period of bioreactor culture in transgenic callus. TC3 $(100 \mathrm{mg})$ cryopreserved in liquid nitrogen was used to extract total RNA and pulverized with Tissue-Lyser II (QIAGEN, Germany). Total RNA was extracted from the transgenic callus following the protocol of the NucleoSpin ${ }^{\circledR}$ RNA Plant and Fungi kit (MACHEREY-NAGEL GmbH \& Co., Germany). The extracted total RNA was used for cDNA synthesis using ReverTra Ace ${ }^{\circledR}$ qPCR Master Mix (TOYOBO, Japan), which was then diluted to a concentration of $100 \mathrm{ng} \mu \mathrm{L}^{-1}$. For RT-qPCR, we mixed a $20 \mu \mathrm{L}$ reaction containing $10 \mu \mathrm{L}$ TB Green Premix Ex Taq (Takara, Japan), $0.5 \mu \mathrm{L}$ of each forward primer and reverse primer, $7 \mu \mathrm{L}$ sterile distilled water, and $2 \mu \mathrm{L}$ of cDNA and performed miraculin gene expression analysis using the CFX96 Touch $^{\mathrm{TM}}$ Real-Time PCR System (Bio-Rad, California). The miraculin gene was amplified using primers miraculin-RT Fw (5'-CATCAATTTCTCGGCGTTCAT$3^{\prime}$ ) and miraculin-RT Rv (5'-AAACCACTACCACAA AACTCCT- $3^{\prime}$ ). As a reference, the DcActin gene was used for normalization.

\section{Miraculin protein analysis}

SDS-PAGE analysis was performed to confirm the production of miraculin protein in TC cultured in a bioreactor. TC3 $(200 \mathrm{mg})$ was pulverized with Tissue-Lyser II (QIAGEN, Germany) in $400 \mu \mathrm{L}$ protein extraction buffer $(500 \mu \mathrm{L}$ of $3 \mathrm{M} \mathrm{NaCl}, 200 \mu \mathrm{L}$ of $1 \mathrm{M}$ Tris (pH 7.5), $20 \mu \mathrm{L}$ of $0.5 \mathrm{M}$ EDTA, $1 \mathrm{~mL}$ of $10 \%$ Triton X-100, $100 \mu \mathrm{L}$ of $10 \%$ SDS, $10 \mu \mathrm{L}$ of $1 \mathrm{M}$ dithiothreitol (DTT), and $10 \mu \mathrm{L}$ of protease inhibitor cocktail. After pulverizing, the supernatant separated from the sample was transferred to a new tube by centrifugation at $13,500 \mathrm{rpm}$. The supernatant was used for SDS-PAGE analysis and protein concentration was examined according to Bradford assay (1976). The TSP was quantitated at the concentration of $30 \mu \mathrm{g} \mathrm{L}^{-1}$ with distilled water, and then we mixed $24 \mu \mathrm{L}$ of the diluted TSP and $6 \mu \mathrm{L}$ of $5 \mathrm{X}$ protein sample buffer (ELPIS, Korea). Samples were incubated at $95{ }^{\circ} \mathrm{C}$ for 5 min and loaded onto an Express-PlusTM PAGE Gel (GenScript, USA) containing Bis-Tris 10\% MOPS buffer. Then, TSP was separated by SDS-PAGE using a MiniSlab Chamber (ATTO, Japan) at $140 \mathrm{~V}$ for $55 \mathrm{~min}$; bright BAND (ZEPTO, Taiwan) was used as a protein marker. After the electrophoresis was completed, the gel was dyed with EzStainAQua (ATTO, Japan) solution for $1 \mathrm{~h}$ and washed three times with distilled water for $30 \mathrm{~min}$ each.

\section{Enzyme-linked immunosorbent assay (ELISA)}

The yield of FLAG-tagged miraculin protein was quantified by ELISA using the DYKDDDDK-Tag Detection ELISA Kit (Cayman, Germany). Absorbance was measured at $450 \mathrm{~nm}$ using Optizen POP (Mecasys Co., Korea).

\section{Statistical analysis}

One-way analysis of variance (ANOVA) analysis was used to indicate significant differences in the data. Statistical processing of the data was done by Duncan's multiple test at $5 \%$ significance level. Analyzes were performed using the SAS program (version 9.4; SAS Institute Inc. Cary, NC, USA).

\section{Results}

Treatment of TC3 liquid suspension culture with different concentrations of $\mathrm{H}_{2} \mathrm{O}_{2}$ and $\mathrm{NaCl}$ for $8 \mathrm{~h}$ significantly up-regulated the expression of the miraculin gene compared with the control (Fig. 1). Among various treatments, $880 \mu \mathrm{M} \mathrm{H} \mathrm{H}_{2} \mathrm{O}_{2}$ and $200 \mathrm{mM} \mathrm{NaCl}$ resulted in the highest miraculin expression, and treatment with $200 \mathrm{mM} \mathrm{NaCl}$ showed the highest expression rate (fivefold greater than the control). On the other hand, ABA, $\mathrm{SA}$ and MeJA treatments did not show noticeably difference in miraculin expression compared to the control (Fig. 1).

The TC3 cells were cultured under six different types of lights to verify the effect of light quality. Fresh weight of TC was the highest $\left(1.7 \mathrm{~g}\right.$ mass $\left.^{-1}\right)$ under blue light (B treatment) and lowest $\left(0.8 \mathrm{~g} \mathrm{mass}^{-1}\right)$ under red light ( $\mathrm{R}$ treatment), indicating a 2.0 -fold difference between these two treatments (Fig. 2). Chlorophyll and carotenoid contents were highest in W, RB, and RGB treatments and highest in B treatment (Fig. 3a). Expression of the miraculin gene was optimum in dark condition and relatively high in W and RGB treatments (Fig. 3b). Miraculin expression was associated with pigment contents. Interestingly, treatments associated with low pigment contents showed high miraculin expression (Fig. 3b). Moreover, correlation analysis confirmed a negative correlation between miraculin expression and chlorophyll content (Fig. 3c). 

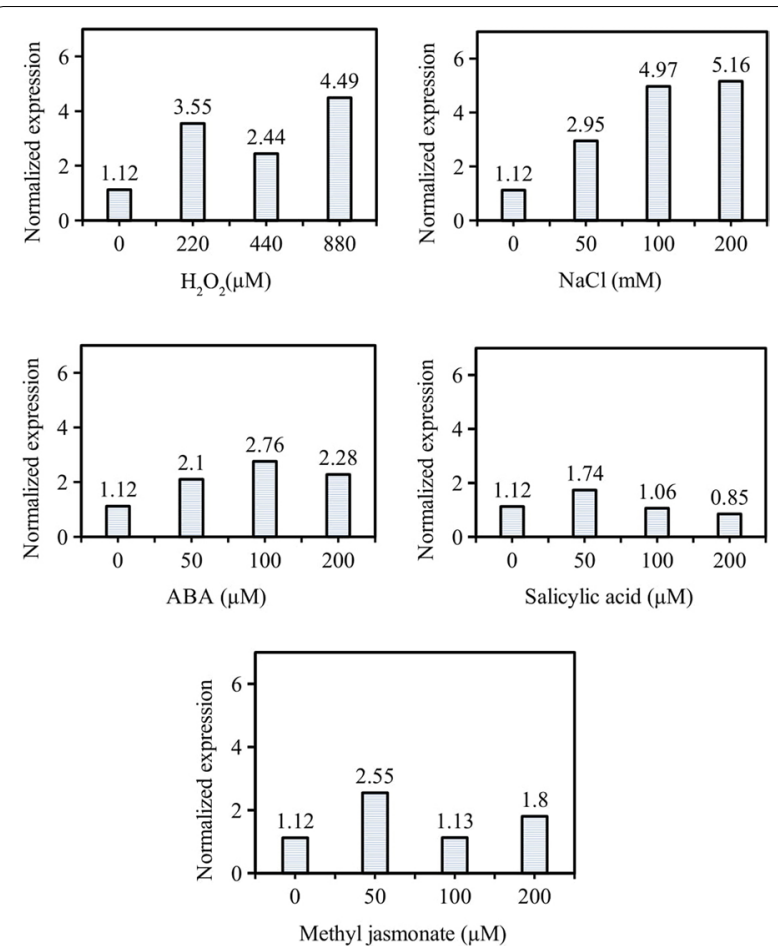

Fig. 1 Miraculin gene expression in transgenic callus under abiotic stress treatments. Data represent mean \pm SE $(n=5)$. Different lowercase letters indicate statistically significant differences at $P<0.05$ (Duncan's multiple range test)

TC3 cell lines were cultured in airlift bioreactors and analyzed the fresh weight and miraculin expression. The fresh weight of TC3 increased slowly until day 6 since the start of culture (lag phase), increased rapidly from day 6 to day 12 (exponential phase), and then decreased thereafter (Fig. 4a, b). Miraculin expression was also the highest at 6 days of culture and decreased at 12 days of culture (Fig. 5a).

Analysis of the TSP by SDS-PAGE confirmed the production of miraculin protein according to the bioreactor culture period. The results of SDS-PAGE showed expression of miraculin protein in all the cell lines (Fig. 5b). We also performed ELISA to confirm the yield of miraculin protein in the bioreactor cultures. The content of miraculin was $0.024 \mu \mathrm{g} \mu \mathrm{L}^{-1}(0.98 \%$ of TSP) at 6 days and $0.013 \mu \mathrm{g} \mu \mathrm{L}^{-1}(0.64 \%$ of TSP) at 12 days (Table 1$)$. These results indicate that the production of miraculin in bioreactors increased approximately 30 - to 90 -fold compared with the recombinant miraculin content produced at 0 -day of TC (0.01\% of TSP) (Table 1$)$.

\section{Discussion}

In the present study, miraulin gene which was tagged to SWPA2 promoter, cloned carrot cell lines and transformed cell lines were used for production of recombinant protein. The effect of $\mathrm{H}_{2} \mathrm{O}_{2}, \mathrm{NaCl}, \mathrm{ABA}, \mathrm{SA}$ and $\mathrm{MeJA}$ were tested on the expression of miraculin gene in the transformed (TC3) cell line (Fig. 1). Among various treatments, $880 \mu \mathrm{M} \mathrm{H}_{2} \mathrm{O}_{2}$ and $200 \mathrm{mM} \mathrm{NaCl}$ resulted in the highest miraculin expression, and treatment with $200 \mathrm{mM} \mathrm{NaCl}$ showed the highest expression rate (fivefold greater than the control). However, the ABA, SA and MeJA treatments did not show considerable difference in miraculin expression compared to the control (Fig. 1). Kim et al. (2004) reported that the stress-inducible SWPA2 promoter used in this study is regulated by peroxidase (POD), which is induced by oxidative stress. Additionally, $\mathrm{H}_{2} \mathrm{O}_{2}$, one of the reactive oxygen species (ROS), is not only a reactive substance for POD but also a signaling molecule directly involved in various stresses such as oxidative stress (Neill et al. 2002). Stress caused by higher concentrations of $\mathrm{NaCl}$ is known to induce
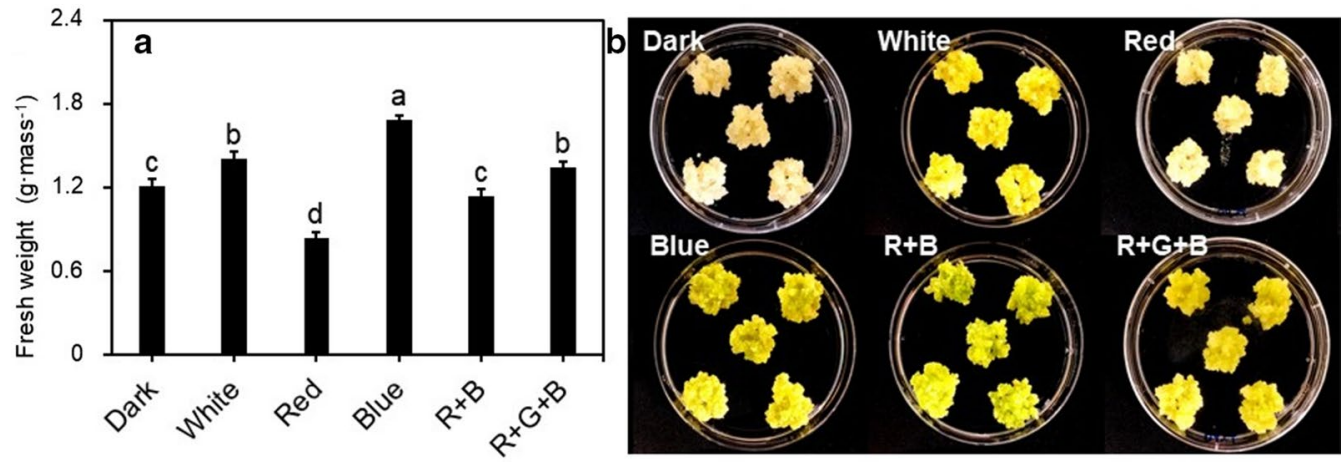

Fig. 2 Effect of light quality on the fresh weight of transgenic callus. a Fresh weight of callus cultured under different light quality; $\mathbf{b}$ callus growth after 4 weeks of culture. Data represent mean \pm SE $(n=5)$. Different lowercase letters indicate statistically significant differences $(P<0.05$; Duncan's multiple range test) 


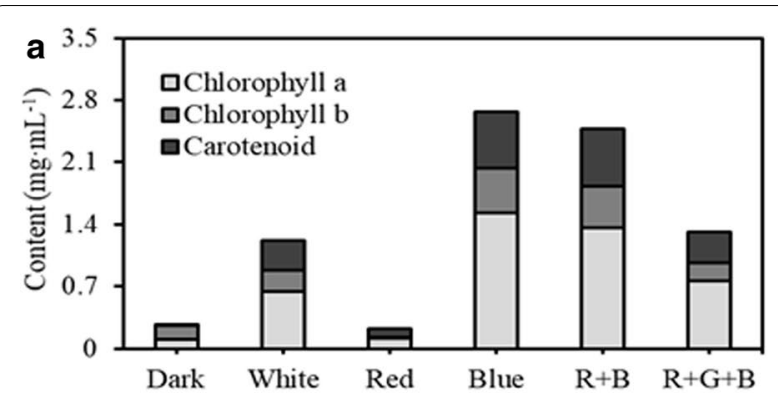

b

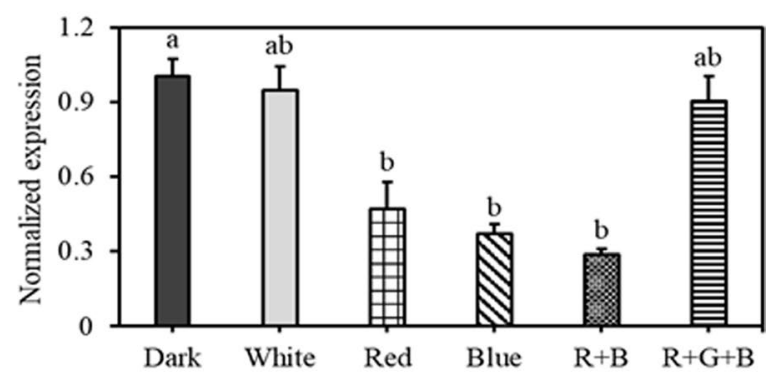

C

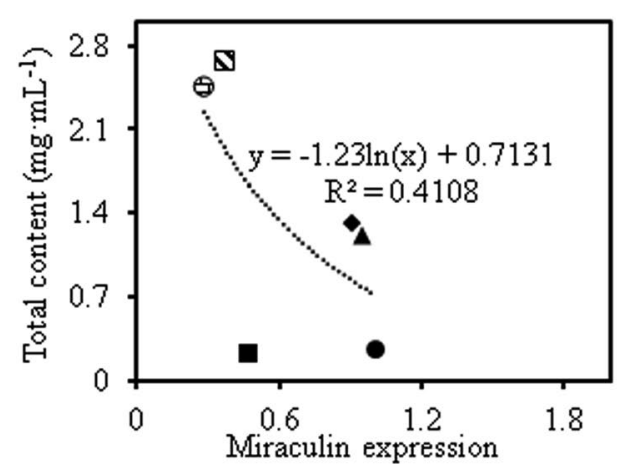

Fig. 3 The relation between chlorophyll content and miraculin expression from transgenic carrot callus cultured under different light qualities. a Chlorophyll and carotenoid contents of transgenic callus; b Miraculin expression in transgenic callus; c Correlation analysis of chlorophyll, carotenoid with miraculin expression. Transgenic callus grown in the dark served as a control. Data represent mean $\pm \mathrm{SE}$ $(n=5)$. The value of control was taken as 1 to compare with transformed callus line. Different lowercase letters indicate statistically significant differences ( $P<0.05$; Duncan's multiple range test)
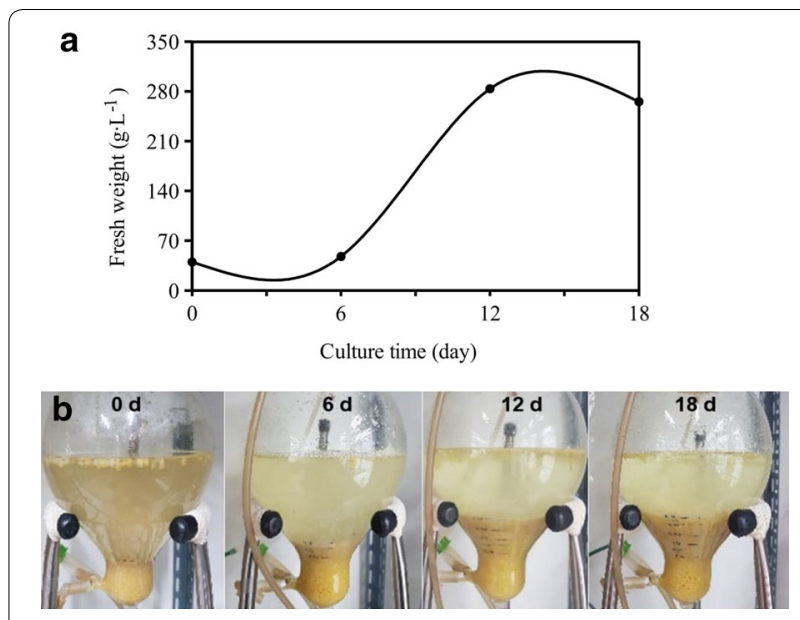

Fig. 4 Cell growth of transgenic carrot callus in air-lift bioreactor during culture period. a Packaged cell growth in bioreactor; $\mathbf{b}$ Fresh weight per liter medium

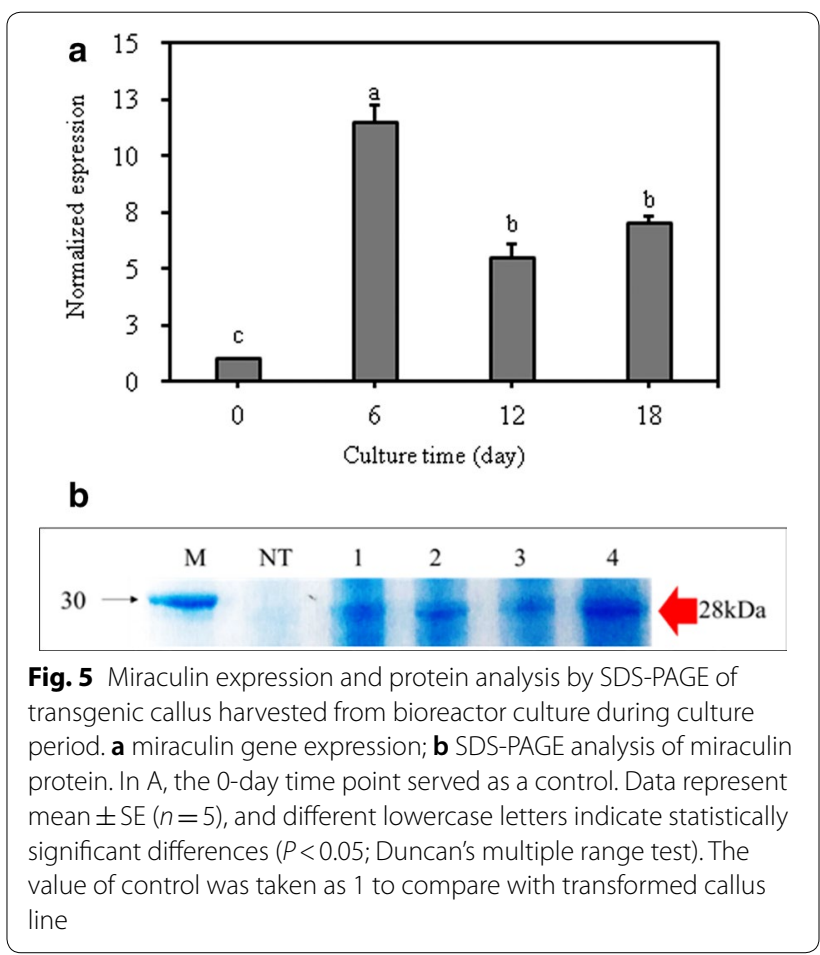

the production of ROS in cells (Tian et al. 2016), which causes oxidative stress, leading to an increase in the content of POD to reduce ROS from plants (Foyer and Noctor 2005). These data suggest that the treatment of TC lines with $\mathrm{NaCl}$ and $\mathrm{H}_{2} \mathrm{O}_{2}$, which directly or indirectly induce oxidative stress, increases the activity of the SWPA2 promoter, resulting in high miraculin expression.

In another set of experiments, we verified the effect of various light sources on TC3 cell line for the production of miraculin protein. In general, dark condition was maintained during the cell cultures. However, in current experiments, $\mathrm{B}, \mathrm{RGB}$, and $\mathrm{W}$ treatments resulted in a highest fresh weight cells. B treatment is closely related to microtubule biosynthesis genes, serine carboxypeptidase, chlorophyll biosynthesis, sugar degradation, and expression of various resistance-related genes ( $\mathrm{Li}$ et al. 2017; Batista et al. 2018). Li et al. (2017) demonstrated 
Table 1 Concentration of miraculin protein extracted from transgenic callus cultured in an air-lift bioreactor

\begin{tabular}{llll}
\hline $\begin{array}{l}\text { Culture } \\
\text { period } \\
\text { (day) }\end{array}$ & $\begin{array}{l}\text { Total soluble } \\
\text { protein }(\mathrm{TSP})(\boldsymbol{\mu g} /\end{array}$ & $\begin{array}{l}\text { Purified miraculin } \\
\text { protein }(\boldsymbol{\mu g} / \mathrm{mL})\end{array}$ & Purity (\% TSP) \\
\hline 0 & 2.366 & 0.0001 & 0.01 \\
6 & 2.412 & 0.0237 & 0.98 \\
12 & 2.070 & 0.0132 & 0.64 \\
18 & 1.805 & 0.0013 & 0.07 \\
\hline
\end{tabular}

that B treatment increases protoplast development and leaf growth in grape. The increase in the fresh weight of transgenic carrot cell line (TC3) upon treatment with blue light might be due to increased biosynthesis of cell growth-related substances such as intracellular microtubules. Plant cells possess photoreceptors such as phytochrome and cryptochrome, and the amount of light absorption by these photoreceptors varies with the light environment (Jiao et al. 2007). Cryptochrome recognizes the wavelength range from ultraviolet A (UV-A) to the blue light region, and phototropin, a photoreceptor, especially absorbs light in this region. Blue light absorbed by phototropin promotes chlorophyll biosynthesis and chloroplast development, resulting in the highest chlorophyll and carotenoid contents (Batista et al. 2018).

The performance of transformed cell line TC3 in bioreactor cultures was studied and results revealed that the fresh weight of TC3 increased slowly until day 6 since the start of culture (lag phase), increased rapidly from day 6 to day 12 (exponential phase), and then decreased thereafter (Fig. 4a, b). Miraculin expression was also the highest at 6 days of culture and decreased at 12 days of culture (Fig. 5a). Polymenis and Aramayo (2015) found that protein is one of the most abundant macromolecules in actively dividing cells. Therefore, it was thought that the expression of miraculin was the highest at 6 days after bioreactor culture in which cell division became active. Furthermore, TC3 cell lines were cultured in airlift bioreactors showed better biomass and miraculin expression (Fig. 5a and Table 1). According to Egelkrout et al. (2012), the efficiency of foreign protein production varies with the host plant, transformation method, and protein storage location. The host plant is one of the most important factors because the amount of foreign protein production depends on the content of endogenous proteins. Because the total amount of protein that plants can biosynthesize is limited, the higher the endogenous protein content, the higher the foreign protein content. When the total protein content is limited, the production of foreign protein often competes with that of endogenous proteins
(Egelkrout et al. 2012). Thus, the negative correlation detected in this study between miraculin expression and chlorophyll content probably resulted from the primary metabolite competition between endogenous chlorophyll biosynthesis and recombinant miraculin expression. Previous studies on recombinant protein production have not reported correlations between expression of recombinant protein and biosynthesis of chlorophyll and carotenoids. Thus, this is the first report on the correlation between recombinant protein production and pigment biosynthesis. Sun et al. (2006, 2007) developed transgenic lettuce and tomato plants for the production of miraculin protein. However, the level of miraculin accumulation was varied in transgenic progenies (To, T1, T2 and subsequent progenies). Further, Sun et al. $(2006,2007)$ reported the variability in miraculin concentrations in leaves/fruits of transgenic lettuce and tomato plants; this hampers the constant and continuous production of miraculin protein. In the current studies, we have demonstrated the cloning of miraculin gene to carrot callus lines and these lines could be used for constant and continuous production of miraculin protein within short period of time.

In conclusion, in the present study, we attempted to increase miraculin expression in transformed carrot cell lines using various abiotic stress treatments. Miraculin expression was up to fivefold higher in TC treated with $\mathrm{H}_{2} \mathrm{O}_{2}$ and $\mathrm{NaCl}$ compared with control. Additionally, high miraculin expression was observed when cultured under W, RGB, and dark conditions. Moreover, air-lift bioreactor increased the production of miraculin protein by 30 - to 90 -fold compared with semi-solid culture, confirming the possibility of mass production. Overall, this study provides basic data for the industrial use of miraculin using transformed carrot cell lines.

\section{Acknowledgements}

Authors thank to Dr. Sang-Soo Kwak of Korea Research Institute of Bioscience and Biotechnology KRIBB for providing SWPA promotor for the study.

\section{Authors' contributions}

YJP acquired data and wrote the manuscript, and JEH participated in analysis of protein. $\mathrm{HL}, \mathrm{YJJ}$ and $\mathrm{HNM}$ participated in interpretation of data and revision for important intellectual content. SYP conceptualized and designed the study. All authors read and approved the final manuscript.

\section{Funding}

This work was supported by a grant from the Next Generation BioGreen21 Program (Project No. PJ013689), Rural Development Administration, Republic of Korea.

Availability of data and materials

All the relevant data is presented in the manuscript.

Ethics approval and consent to participate

This article does not contain any studies with human participants or animals performed by any of the authors. 


\section{Consent for publication}

All authors have given their consent for publication.

\section{Completing interests}

The authors declare that they have no competing interests.

\section{Author details}

${ }^{1}$ Department of Horticulture, Division of Animal, Horticultural and Food Sciences, Chungbuk National University, Cheongju 28644, Republic of Korea. ${ }^{2}$ Department of Forest Genetic Resources, National Institute of Forest Science, 39 Onjeong-ro, Suwon 16631, Republic of Korea. ${ }^{3}$ Department of Horticultural Life Science, Hankyong National University, Anseong 17579, Republic of Korea.

${ }^{4}$ Department of Botany, Karnatak University, Dharwad 580003, India.

Received: 5 March 2020 Accepted: 8 August 2020

Published online: 13 August 2020

\section{References}

Batista DS, Felipe SS, Silva TD, Castro KM, Mamedes-Rodriques TC, Miranda NA, Ríos-Ríos AM, Faria DV, Fortini EA, Chagas K, Torres-Silva G, Xavier A, Arencibia AD, Otoni WC (2018) Light quality in plant tissue culture: does it matter? Cell Dev Biol Plant 54:1-21

Boamponsem GA, Leung DWM (2017) Use of compact and friable callus cultures to study adaptive morphological and biochemical responses of potato (Solanum tuberosum) to iron supply. Sci Hortic 219:161-172

Bradford MM (1976) A rapid and sensitive method for the quantitation of microgram quantities of protein utilizing the principle of protein-dye binding. Anal Biochem 72:248-254

Corbin JM, Hashimoto BI, Karuppanan K, Kyser ZR, Wu L, Roberts BA, Noe AR, Rodriguez RL, McDonald KA, Nandi S (2016) Semicontinuous bioreactor production of recombinant butyrylcholinesterase in transgenic rice cell suspension cultures. Plant Biotechnol 7:1-10

Egelkrout E, Rajan V, Howard JA (2012) Overproduction of recombinant proteins in plants. Plant Sci 184:83-101

Eibl R, Eibl D (2008) Design and use of the wave bioreactor for plant cell culture. Phytochem Rev 7:593-598

Ezura H, Hiwasa-Tanase K (2018) Mass production of the taste-modifying protein miraculin in transgenic plants. In: Merillon JM, Ramawat K (eds) Sweeteners, reference series in phytochemistry. Springer, Cham, pp 1-18

Foyer CH, Noctor G (2005) Oxidant and antioxidant signalling in plants: a reevaluation of the concept of oxidative stress in a physiological context. Plant Cell Environ 28:1056-1071

Hellwig S, Drossard J, Twyman RM, Fischer R (2004) Plant cell cultures for the production of recombinant proteins. Nat Biotechnol 22:1415-1422

Huang TK, McDonald KA (2009) Bioreactor engineering for recombinant protein production in plant cell suspension cultures. Biochem Eng J 45:168-184
Huang TK, McDonald KA (2012) Bioreactor systems for in vitro production of foreign proteins using plant cell cultures. Biotechnol Adv 30:398-409

Huang TK, Falk BW, Danekar AM, McDonald KA (2018) Enhancement of recombinant protein production in transgenic Nicotiana benthamiana plant cell suspension cultures with co-cultivation of Agrobacterium containing silencing suppressors. Int J Mol Sci 19:1561

Jiao Y, Lau OS, Deng XW (2007) Light regulated transcriptional networks in higher plants. Nat Rev Genet 8:217-230

Jin SB, Sun HJ, Bachchu MAA, Chung SJ, Lee J, Han SI, Yun JH, Boo KW, Lee D, Riu KZ, Kim JH (2013) Production of recombinat miraculin protein using transgenic citrus cell suspension culture system. J Korean Sco Appl Biol Chem 56:271-274

Kim KY, Kwon SY, Lee HS, Hur Y, Bang JW, Kwak SS (2003) A novel oxidative stress-inducible peroxidase promotor from sweet potato: molecular cloning and characterization in transgenic tobacco plants and cultured cells. Plant Mo Biol 51:831-838

Kim YH, Ryu SH, Kim KY, Kwon SY, Bang JW, Kwak SS (2004) Induction of a sweet potato anion peroxidase swpa2 gene expression by stress-related chemicals and Pectobacterium chrysanthemi. Kor J Plant Biotechnol 31:83-88

Li CX, Xu ZG, Dong RQ, Chang SX, Wang LZ, Khalil-Ur-Rehman M, Tao JM (2017) An RNA-Seq analysis of grape plantlets grown in vitro reveals different responses in blue, green, red LED light, and white flurescent light. Frot Plant Sci 8:78

López EG, Ramírez EG, Gúzman OG, Calva GC, Ariza-Castolo A, Pérez-Vargas J, Rodríguez HG (2014) MALDI-TOF characterization of hGH1 produced by hairy root cultures of Brassica oleracea var. italica grown in an airlift with mesh bioreactor. Biotechnol Prog 30:161-171

Neill S, Desikan R, Hancock J (2002) Hydrogen peroxide signaling. Curr Opin Plant Biol 5:388-395

Polymenis M, Aramayo R (2015) Translate to divide: control of the cell cycle by protein synthesis. Microb Cell 2:94-104

Sun HJ, Cui ML, Ma B, Ezura H (2006) Functional expression of the taste-modifying protein, miraculin, in transgenic lettuce. FEBS Lett 580:620-626

Sun HJ, Kataoka H, Yano M, Ezura H (2007) Genetically stable expression of functional miraculin, a new type of alternative sweetener, in transgenic tomato plants. Plant Biotechnol J 5:768-777

Tian L, Li X, Yang R, Gu Z (2016) NaCl treatment improves reactive oxygen metabolism and antioxidant capacity in broccoli sprouts. Hortic Environ Biotechnol 57:640-648

Yano M, Hirai T, Kato K, Hiwasa-Tanase K, Fukuda N, Ezura H (2010) Tomato is a suitable material for producing recombinant miraculin protein in genetically stable manner. Plant Sci 178:469-473

\section{Publisher's Note}

Springer Nature remains neutral with regard to jurisdictional claims in published maps and institutional affiliations.

\section{Submit your manuscript to a SpringerOpen ${ }^{\circ}$ journal and benefit from:}

- Convenient online submission

- Rigorous peer review

- Open access: articles freely available online

- High visibility within the field

- Retaining the copyright to your article

Submit your next manuscript at springeropen.com 